Andrzej Ćwiek

Poznań

\title{
RED AND BLACK WORLD
}

Abstract: The red and black formed in Egypt a système antinomique (B. Mathieu). Desheret (the desert) represented the sphere of the wild and the natural, while kemet (alluvial land) signified cultivated and civilised areas. These were not the only opposites involved. The red desert was seen as the source, base and place of origin of the black land and its inhabitants. This could also be compared to the raw vs worked (natural $v s$ artificial) relationship. At the same time, it reflected the relationships between Seth and Osiris, evil and good and chaos and order. In developed Egyptian cosmology and eschatology, red represented $R a$, day, life and activeness against black, which represented Osiris, night, death/rebirth and potential states. From these connections, red/divine and black/royal connotations emerged. Examples of the use of red and black can be found in both architecture and art from Naqada I vessels through to New Kingdom obelisks. This reflects the fundamental ideology of these colours.

Keywords: Dualism; symbolic role of colours; Egyptian art

The Egyptian view of the world was based on dualisms (Servajean 2013). They governed both description and interpretation, reflecting the duality integral to the structure of the world itself. The two elements were conceived either as opposites or as complementary to each other. Sometimes they were even considered both opposite and complementary at the same ime. One of the most basic aspects of the description and categorisation of the world was colour (Wilkinson 1994, 104-125; Aufrère 1998; Baines 2007, 240-262). Pairs of colours such as white and red, red and yellow and black and white played an important symbolic role in texts and imagery. The case of red and black is particularly significant. These colours were 
the two most basic ${ }^{1}$ and in ancient Egypt they formed the primitive palette alongside white. This was enriched from the Old Kingdom onwards by yellow, green, blue and grey (Baines 2007, 243-249). When red and black were paired they formed a système antinomique (Mathieu 2009, 29-30), but in many contexts they complemented each other. In ancient Egypt, black was semantically related to Nile mud, night, death and fertility, whilst red represented blood, fire, the sun, the desert and life. The precise meaning of the colour was therefore neither simple nor did it possess an intrinsic significance. Instead, meaning was determined by context (Robins 2002, 293).

The two colours in question were $5 \mathrm{~km}$ (be) black and var. $\bigcirc d \check{s} r$ (be) red. In a variant orthography, $\longrightarrow$, the word $d \check{s} r$ is represented by a hieroglyph of a sparrow (G 37 of Gardiner's Sign List) with the meaning of 'bad' or 'small', reflecting the negative connotations of the colour. 'Red Land (= desert)' derived from these terms. The pharaoh was not only the king of Upper and Lower Egypt, but also the 'king of the Black Land, ruler of the Red Land' (inscription on Amenhotep III's statue from the Luxor cache; Murnane 1995, 19).

Red 'was considered a very potent colour, hot and dangerous, but also life-giving and protective. It is both the colour of blood, a substance that relates to life and death, and of fire, which may be beneficial or destructive. It is also a colour frequently given to the sun, which may be red at its rising or at its setting, and which can overwhelm with its heat or warm to bring life.' (Robins 2002, 292; cf. Griffiths 1972; Pinch 2001). Black 'was considered the colour of fertile soil of $k m t$ ('the Black Land'), one of the names for Egypt; it therefore carried connotations of fertility and regeneration.'(Robins 2002, 291).

At the dawn of their culture, the Egyptians entered the valley from the desert (Aufrère 2001, 158-159; Friedman 2002). From this point on, these two distinct geographical spheres were interconnected, but preserved their fundamentally different characters. The original contrast of the red desert against the black cultivated area gradually developed into more

\footnotetext{
1 Mammals mostly see in only black and red and the primitive red-black vision of humans was only in time differentiated into more colours. It can also be noted that the complementary and/or opposite roles of red and black in dichotomic descriptions of the world can be found in many cultures and contexts, including the colour of playing cards; red for hearts and diamonds, black for spades and clubs.
} 
complex antinomies: wild - civilised, raw - artificial, nature - culture (Pl. 1: 1). It is probable that these connotations were present in the Egyptian consciousness as early as the Predynastic period. Collared jars with matte red surfaces and egg-shaped pots finished in shiny black have been recorded in the funerary structures of HK6, as well as in the ritual enclosure of HK29A at Hierakonpolis. They might have had a 'symbolic significance associated with the coming of the Nile flood when the dry (matte) red land would become fertile ('shiny') black land. The presence of such unique vessels at HK6 and HK29A suggests both had broadly similar, but not identical, ritual requirements, which can be presumed to relate to the concept of rebirth, be it of the deceased elite or the land and cosmic order, and indicates a close connection between the two.' (Friedman $2009,88)$. It has also been suggested that black-topped vases of the time might have come from 'la culture agricole, serait alors celle d'une sorte de bornage territorial, la terre noir cultivée, délimitant l'extension du domaine désertique rouge...' (Mathieu 2009, 29) (Fig. 1). This primitive dichotomy was the basis for all further developments of red and black symbolism.

Of a fundamental nature to Egyptian cosmogony was the gradual differentiation of the world into basic elements following the dualistic principle: Shu and Tefnut $=$ light void and humidity, Geb and Nut $=$ earth and sky, Osiris (+Isis) and Seth (+Nephthys) = civilisation and wilderness, cultivated land and wild desert, fecundity and sterility. In the case of the last combination, both aspects are indispensable and interconnected. In myth, this is represented by Seth (personifying the red, infertile desert) and Osiris (connected with the fertile soil of the Nile valley). The killing of Osiris by Seth was a precondition for the god's rebirth (Fig. 2). Life was thus related to red and rebirth

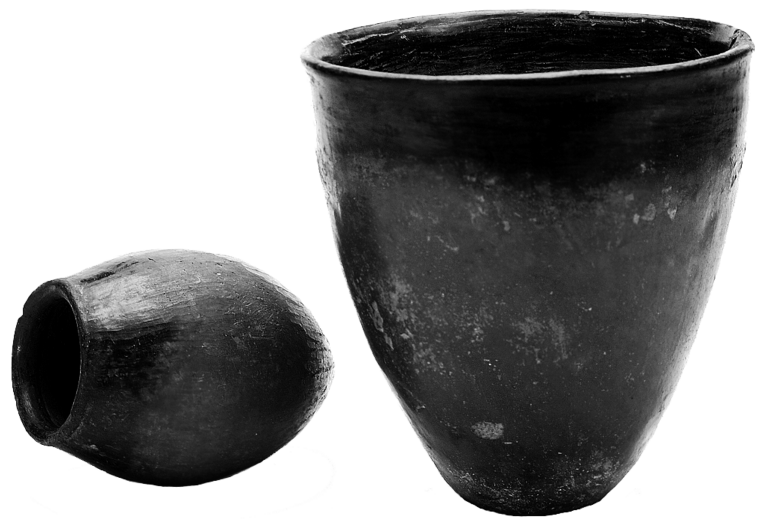

Fig 1. Black-topped vessels, Naqada I, Poznań Archaeological Museum inv. nos 1986:3/1-2. Photo by P. Silska 


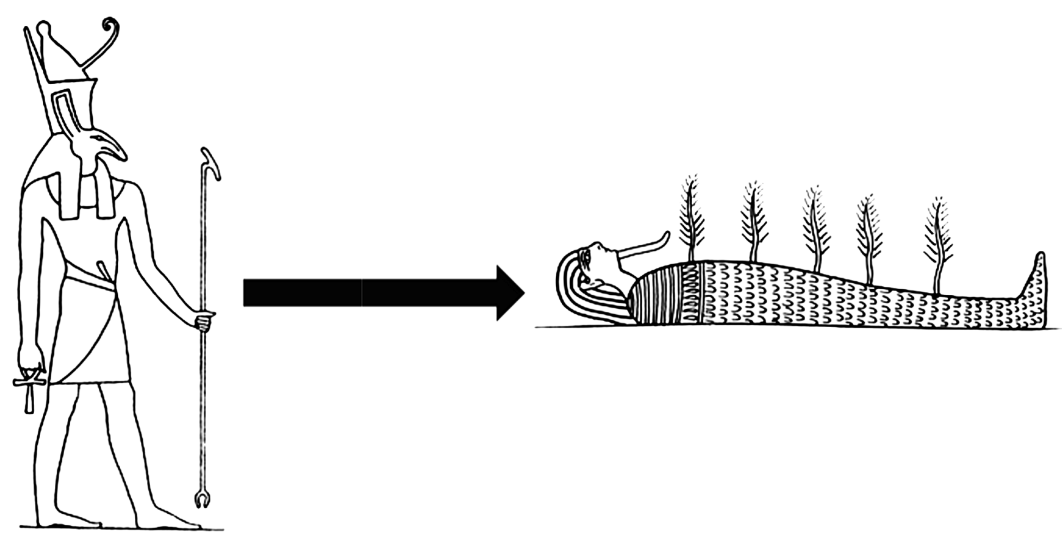

Fig. 2. Red to black: Seth and Osiris. Drawing by the author

to black. ${ }^{2}$ Indeed, this formed the basis for the eternal cycle of life transformation concept, which emerges in its red, active form from the black before eventually turning back into black to be restored and start the cycle again.

With respect to Seth, 'the dangerous, uncontrolled aspects of red connected the colour to notions of anger, as in the expression $d \check{s} r j b$ ("red of heart"), meaning "furious" or "raging".' (Robins 2002, 292). In the Pyramid Texts $\S 1269$ c (TP 534), Seth is sent to the Black Mountains to 'make him black', i.e. make him calmer and more civilised (Mathieu 2009, 29).

These primordial meanings were buried deep in the Egyptian consciousness and were also expressed in everyday life. An example of this is the process of creating art. Although it would seem 'natural' that a drawing should be made in black and corrected in red, the opposite procedure occurred. After an apprentice had sketched a drawing (e.g. for a relief) in red, it was given its final shape by a master with black paint. 'Raw' and 'civilised' was thus expressed in a clear manner.

On papyri, headings and some other words were rubrics painted in red ink to mark the names of dangerous gods, such as Seth and Apopis. The name of $\mathrm{Ra}$, however, was always written in black. This reflected the moral values ascribed to black/good and $\mathrm{red} / \mathrm{bad}$.

\footnotetext{
2 The colour black is also representative of gods who occupied the funerary sphere, such as Anubis and Wepwawet, and those who had strong fertility connections, such as Min and Amun-Kamutef.
} 
The spheres in which the red-black antinomy occurs most clearly are cosmology and eschatology (Kees 1943). The eternal cycle of the sun's journey was made up of the day (symbolised by red with the red sun-disk on Ra's head and his epithet $b 3$ jmj dšrw.f, which referred to the red setting sun [Altenmüller 1972, 9-13]) and the night (connected to Osiris and the night sun, with darkness and his black body of rebirth and regeneration) (Fig. 3). Osiris '...was referred to in Egyptian texts as kmjj ("the black one"), which not only alluded to his role in the underworld but also to his resurrection after he was murdered. (...) Osiris was occasionally shown with black skin, to refer to the renewing properties of Egypt's black soil and the underworld.' (Robins 2002, 291). An example of this is the twelfth hour of Amduat, in which Osiris is black and ithyphallic, a clear symbol of his readiness for rebirth. Ra thus signifies day and the path from life to death, whilst Osiris represents the night and the path from death to new life (Pl. 2: 1). At the same time, the properties of the two gods gave the colours the additional connotations of static/passive/potential (black) and

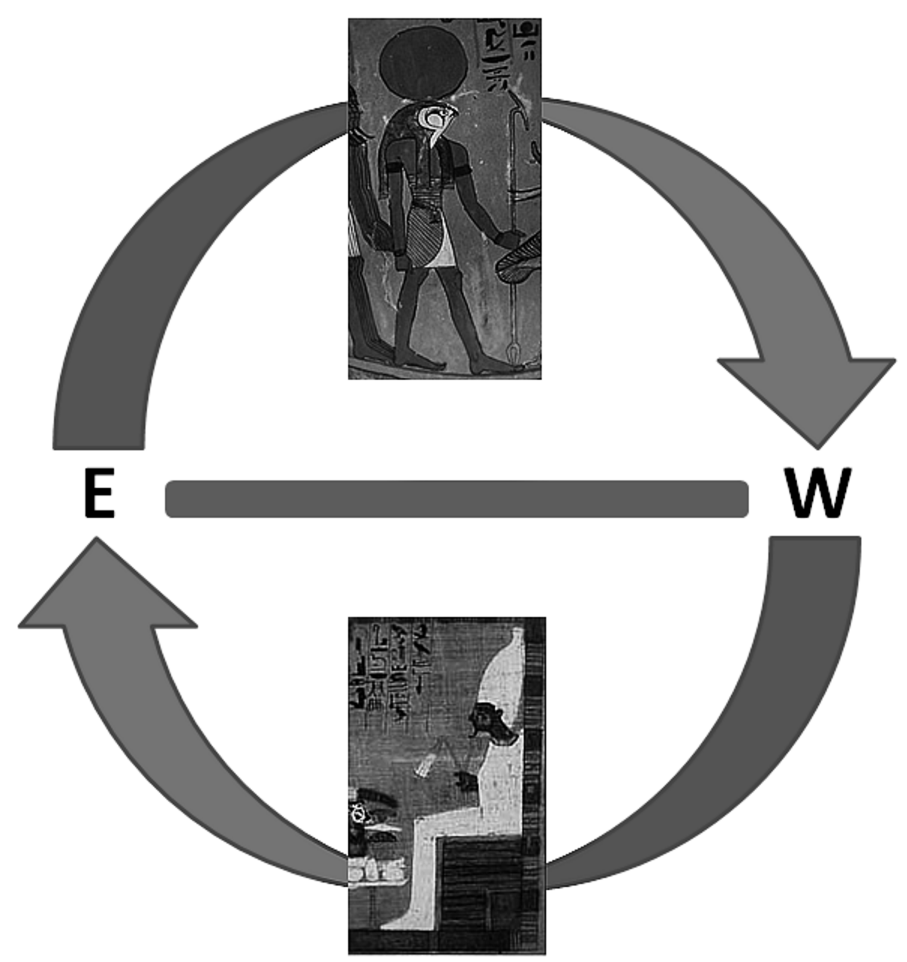

Fig. 3. Ra and Osiris in the cosmological cycle. Photos from the author's archive/public domain 
dynamic/active/realised (red). A geographical connection was also made. Night was related to the north and day to the south, so black and red were linked to directions as well.

The connection of Osiris (originally the embodiment of all dead kings) and the fertile, civilised human land ruled by the pharaoh with black resulted in the 'royal' associations of the colour. Meanwhile, the colour of the sun and desert (more Ra's and Seth's than part of the human sphere) resulted in the 'divine' connotations of red.

The complementary significance of red and black is also immanent in the person of the goddess Hathor. The disk on her head was red, but it was placed on black horns. Hathor was a complex deity, the patroness of the living as well as of the dead. In terms of colour symbolism, red people ${ }^{3}$ lay in the Black Land and black people lived in the Red Land.

This red-black-red connection was used in various ways in Egyptian imagery. Ahmes-Nefertari was depicted with black skin, because she was the royal mother of Amenhotep I and the whole dynastic line. The idea of regeneration was thus symbolised, as she was the black fertile hprw out of which the living red hprw emerged (Manniche 1979). This reflects the strong skin-colour-nature association in both phraseology and iconography (Baines 2007, 245-246).

Another case of the symbolic use of colour for different stages of life is the decoration of a double cartouche-shaped case of Tutankhamun. The figure of the king is variously coloured in semi-cryptographic writing of his prenomen, which represents the different hprw of his life. This should be read as a cycle: yellow (child), red (mature), black (dead), and red (reborn) (Silverman 1980; cf. Manniche 1982).

\section{Red and black paint: reliefs and statuary}

Mentuhotep Nebhepetra was depicted with red skin in reliefs and statuary (e.g. the heads of Osiride statues of the British Museum, inv. no. EA 720, Metropolitan Museum of Art, inv. no. 26.3.29, Museo Gregoriano Egizio, inv. no. 22680) from the temple of Deir el-Bahari, but with black skin in a statue from Bab el-Hosan (P1. 2: 2) and in a relief depicting him suckling from a Hathor cow (Hannover 1935.200.82).

\footnotetext{
3 Skin hues were a matter of strict convention in Egyptian art. The basic division into red men and yellow women was abandoned during the Amarna period and in Ramesside times males and females were usually represented with similar, reddish hues, though goddesses were still yellow. A separate issue is the fact that pink was used for depictions of royal women in the 18th and 19th Dynasties (Ćwiek 2007).
} 
This latter representation stresses the regenerative powers of divine milk. In a statue from Hathor's Shrine of Thutmose III from Deir el-Bahari, however, Amenhotep II is red-skinned in a suckling scene, but black in a figure standing in front of the cow (inv. no. JE 38575; Saleh and Sourouzian 1987, no. 138). Black striding statues of the kings appear in the tombs of the Valley of the Kings, firstly for Hatshepsut and later for Thutmose III, Amenhotep II, Tutankhamun (Pl. 1: 2), Ramesses I and Ramesses IX among others.

Since Egypt was a Staat aus dem Stein (Evers 1929) and stones had various different usages and values (Baines 2007, 263-280), the role of black and red stone is especially meaningful. 'Black stones were used in statuary to evoke the regenerative qualities of Osiris and the renewal of the deceased.' (Robins 2002, 291). 'Stones such as rosy or golden quartzite and red granite had a solar significance because of their colour and they could be used to invoke the regenerative properties of the solar cycle. Royal statuary made of such stones stressed the solar aspect of the kingship' (Robins 2002, 292). The symbolic nature of stones, such as the solar connotations of quartzite (Aufrère 1991, 698-699; Baines 2000, 36), can be found in architecture, as well as in statuary. Several cases of the deliberate simultaneous use of red and black stone in art and architecture can be mentioned:

\section{Old Kingdom pyramid complexes}

In Old Kingdom mortuary complexes, the material used was a matter of deliberate choice and sophisticated usage was made of it (Ćwiek 2003, 321-324). For example, the red granite floral columns rising from the black basalt floors in the courtyards of mortuary temples (Hoffmeier 1993) symbolised plants emerging from Nile mud. In Teti's mortuary temple at Saqqara, the floor in the transverse corridor was made of travertine, but the threshold of the southern entrance was made of red granite and that of the northern entrance of basalt. Such usage of material may reflect a simple 'geographical' pattern. Granite would thus have been used for the south and basalt for the north due to the provenance of these stones. ${ }^{4}$ The royal sarcophagi in the pyramid chambers were made of black greywacke (Wissa 1994), whilst the canopic chests were made of red granite (Dodson 1994).

\footnotetext{
4 A similar 'geographical' pattern of the use of various stones can be observed in Old Kingdom royal statuary, including Khafra's statues in the valley temple and Menkaura's triads (Ćwiek 2003, 313, notes 1294, 1321-1322, 1331).
} 
2. Mortuary complex of Mentuhotep Nebhepetra at Deir el-Bahari

The usage of red and black in the reliefs and statuary of Mentuhotep's tomb complex has already been described above. The tomb of Mentuhotep, which was accessed by a $150 \mathrm{~m}$ long corridor, is also an example of the deliberate use of red and black stone. The burial chamber, hewn out of rock, was lined with red granite blocks. Inside, there was a large travertine shrine with a red granite monolithic roof. Between the shrine and the walls of the chamber was a casing of black diorite (Arnold 1974, 48-49, pls 21-22, $38-40)$. It could be possible that these diorite plates were not placed around the shrine for construction reasons (pace Arnold 1974, 48), but that the final resting place of the king was instead purposefully encased in black stone due to its symbolic regenerative properties.

\section{Red Chapel of Hatshepsut at Karnak}

Hatshepsut carried out an immense building program at Karnak. Her greatest achievement was the Red Chapel, a sanctuary for Amun's divine bark (P1. 3: 1). It is made of red quartzite and black diorite. The walls are mostly made of red quartzite blocks, prefabricated and decorated before assemblage. The diorite blocks form the frame of the building (the lowermost and uppermost layers of blocks for the base and cornice respectively), as well as the door frames of the western and eastern façades (Burgos and Larché 2008, 29-30). Here, the red-divine/solar and black-royal connotations are a clear indication that the ruler is making and 'framing' a dwelling for a deity. This interpretation is corroborated by the decoration of the diorite band surrounding the base of the monument, which presents a traditional royal serekh motif (Fig. 4), as well as by the fact that the lowermost layer of blocks inside the chapel sanctuary and vestibule (inside the god's dwelling) is made of quartzite and not diorite.

In the 'Palace of Maat', where the Red Chapel was once located, the two gates of the northern section were made of black granite, whilst the one in the southern part was made of red granite (Gabolde 2005, 104-105). This 'geographical' principle, which connects the colours of stone with the cardinal points (cf. the evidence from the pyramid temple of Teti above), is also observed in the unique work of the female pharaoh: Hatshepsut.

\section{Temple of Hatshepsut at Deir el-Bahari}

The temple of Deir el-Bahari bears various traces of the symbolic use of material. Its vast and complex statuary once included the most important 


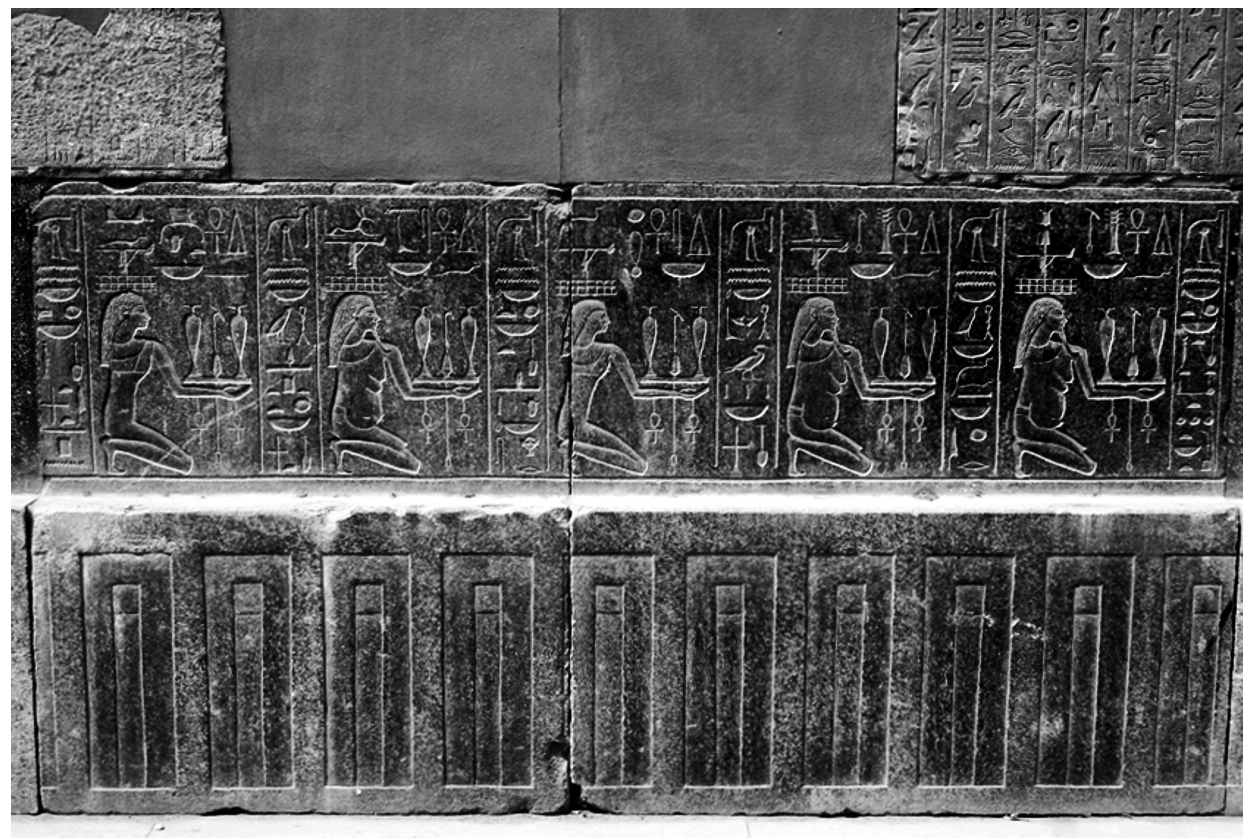

Fig. 4. Detail of the Red Chapel: diorite dado with a serekh motif. Photo by the author

cult figures of the seated Hatshepsut. Since all statues of this female king were removed by Thutmose III when he proscribed her, their original placement in the temple can only be presumed. It now seems possible to suggest that black (grano-)diorite statues of Hatshepsut (inv. no. MMA 30.3.3; Keller 2005, 159) and Thutmose I (inv. no. MMA 31.3.168; Keller 2005, 161, attributed to Hatshepsut), ${ }^{5}$ were once located in the Royal Cult Complex (in the Chapel of Hatshepsut and the Chapel of Thutmose I respectively) and that the red granite statues of Hatshepsut (inv. nos MMA 29.3.3 + Leiden F 1928/9.2; Keller 2005, 170-171; and inv. no. MMA 27.3.163; Keller 2005, 160) were placed in the Solar Cult Complex (P1. 4). This attribution is strongly suggested by the finds of the Polish mission in the temple. Pieces of black diorite were found during excavation of the Royal Cult Complex, whilst fragments of red granite were discovered in the Solar Cult Complex. This fits perfectly with the theory of a reconstructed magic ritual cycle of rebirth and regeneration of the king, which started in the Chapel of Hatshepsut in the Royal Cult Complex in the south and ended

\footnotetext{
5 I am much indebted to Dorothea Arnold for the suggestion that this statue represents Thutmose I and for our inspirational discussion concerning the statuary of Djeser-Djeseru.
} 
in the Solar Cult Complex in the north (Karkowski 2005, 84). ${ }^{6}$ Red granite was solar, whilst black diorite was both royal and Osirian stone. The positioning of red in the north also connects it to the east (sunrise and rebirth), whilst the black in the south reflects a connection to the west (emergence from the Netherworld ${ }^{7}$ ).

A minor but interesting use of red-black 'geographic' symbolism can be noted in the wall decoration of the temple. The pupils in the udjat eyes of the vulture cryptograms in the Hathor Shrine western vestibule wall are coloured red in the northern vulture, but black in the southern vulture (Beaux et al.2012, pl.29). The two colours also appear in the eye hieroglyphs of the Bark Hall, but this time their order is reversed. The pupil is red on the southern wall, but black on the northern wall (these can be seen in scenes with the royal family, cf. Naville 1906, pl. CXLV). It could be speculated that this reversal was an allusion to the concept of blacknorth-night-Osiris-renewal/rebirth and red-south-day-Ra-creation/birth mentioned above. In this context, the north is joined to the west and the south to the east.

These seemingly opposite connotations are not, however, contradictory. Whether a north/red - south/black or north/black - south/red order is adopted, it may still reflect the cycle of the solar journey and represent eternal transformation around an east-north-west-south circle (cf. Westendorf 1966).

\section{The Osireion ('Cenotaph' of Seti at Abydos)}

The Central Hall of the Osireion is built of red granite (pillars and architraves) and red sandstone (walls), but the blocks are joined with dovetail cramps of black granite, which bear names of the king (Frankfort 1933, 17). This may reflect the red-divine and black-royal principle again.

\footnotetext{
${ }^{6}$ It is possible that the two red granite statues of Hatshepsut represented the two consecutive phases of her building programme, which may be reflected by the smaller and larger altar in the solar court. A statue of Thutmose I might have also occurred in the Solar Complex, as a focus of rituals starting at his statue in his offering chapel in the Royal Cult Complex. Another issue is the original placement of the 'White Hatshepsut' (indurated limestone seated statue inv. no. MMA 29.3.2). It is tempting to attribute it to the Main Sanctuary, but this must remain in the realm of mere speculation.

7 Through false doors in the western walls of the Chapel of Hatshepsut and the Chapel of Thutmose I. It seems that the kings were supposed to come from the KV 20, their common tomb in the Valley of the Kings, and (having passed through all regeneration rituals) to return to the tomb through the back (western) wall of a niche in the Upper Anubis Shrine. The need for Anubis' help in this transfer was the reason for the addition of this room to the Solar Cult Complex.
} 

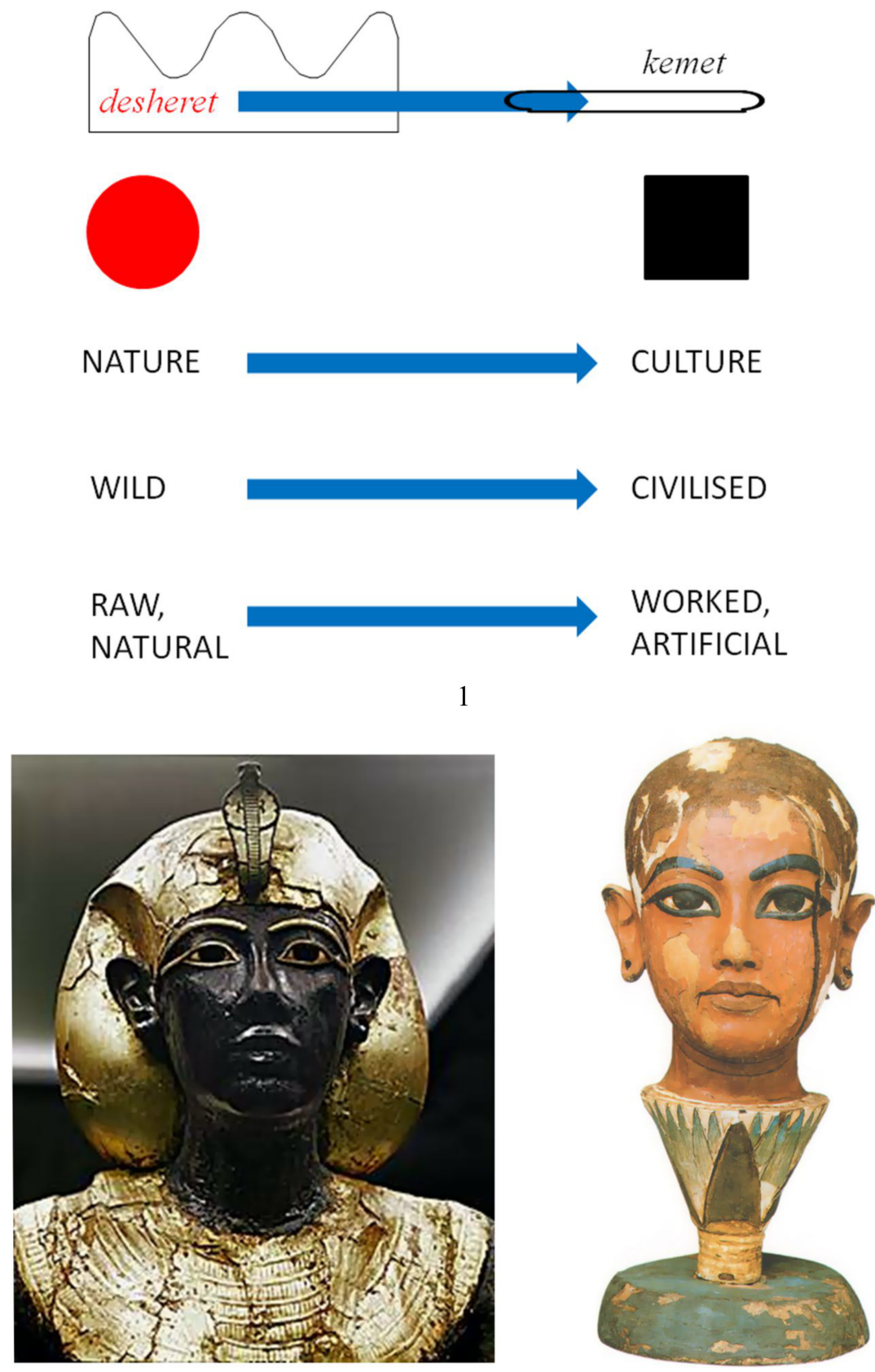

2

Pl. 1: 1 - Relationship of desheret and kemet. Drawing by the author 2 - Red and black images of Tutankhamun.

Photos from the author's archive/public domain 


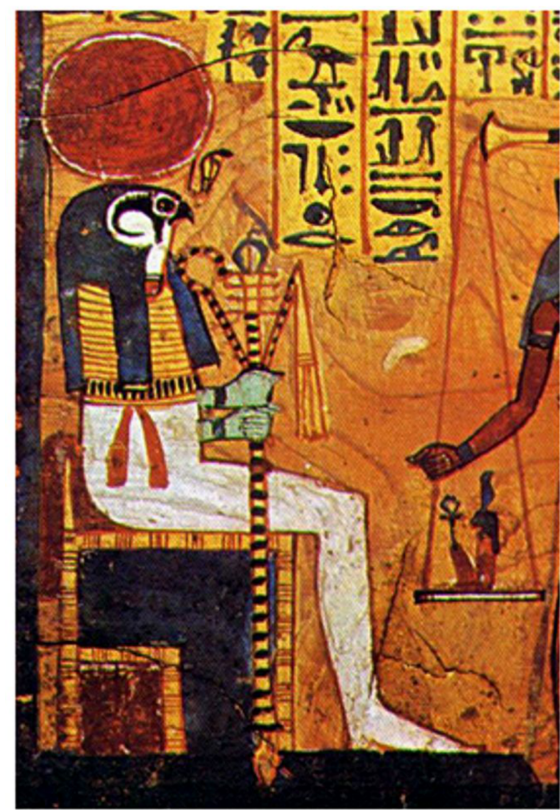

RA

day

life to death

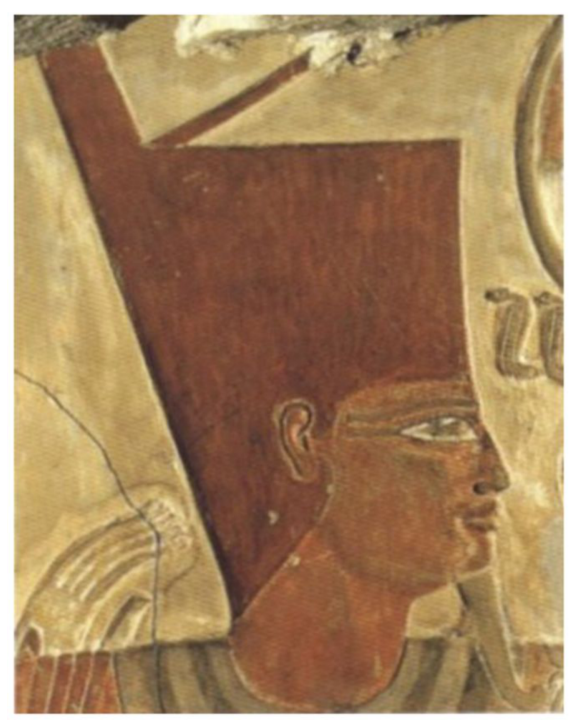

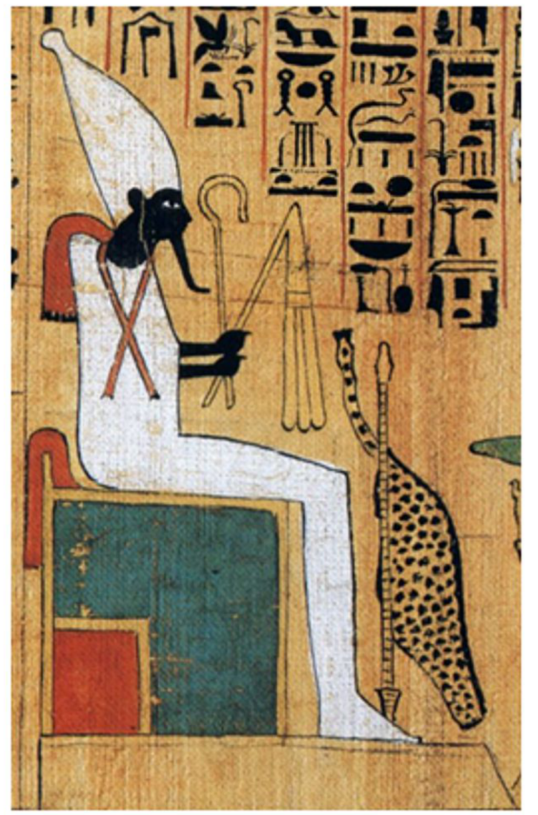

OSIRIS

night

death to rebirth

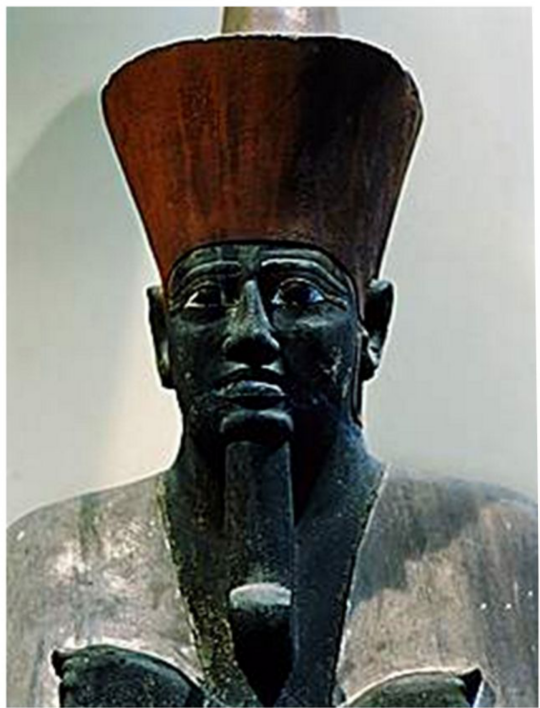

Pl. 2: 1 - Ra and Osiris connotations; 2 - Red and black images of Mentuhotep Nebhepetra. Photo from the author's archive/public domain 


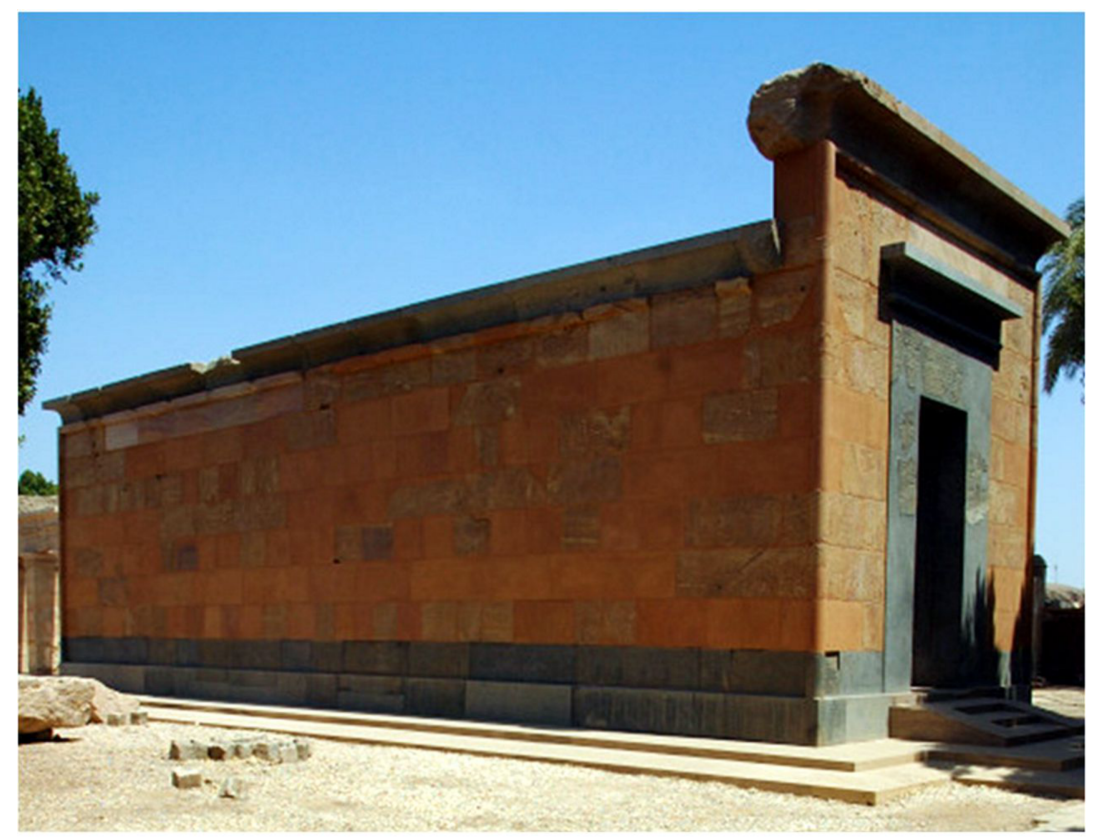

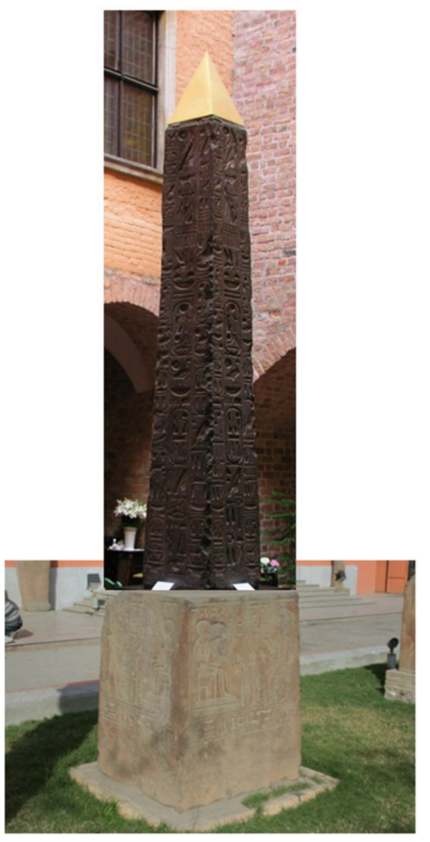

2

1

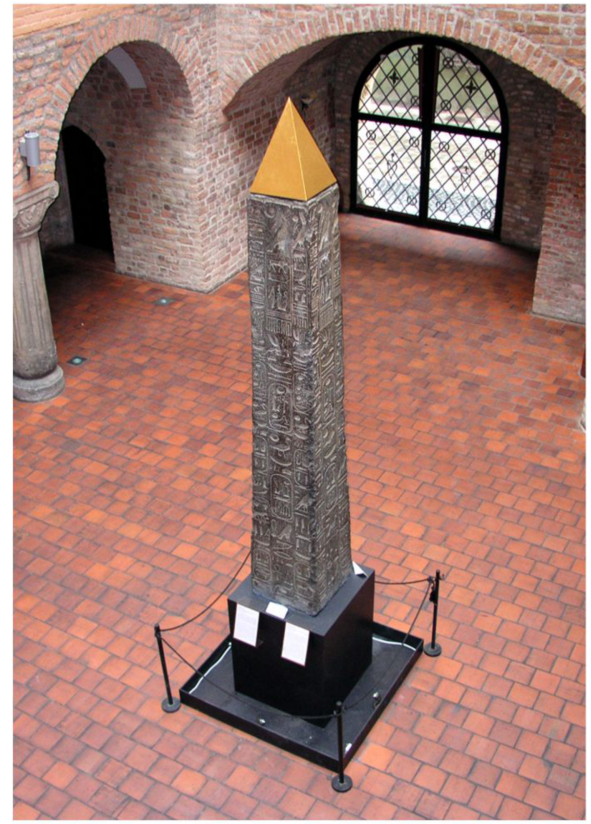

3

Pl. 3: 1 - The Red Chapel of Hatshepsut at Karnak. Photo by the author; 2 -Combined picture of the Athribis obelisk with its base, now in the Cairo Museum garden. Photo by the author; 3 - Obelisk from Athribis, Berlin inv. no. ÄMB 12800; currently at the Poznań Archaeological Museum. Photo by P. Silska 


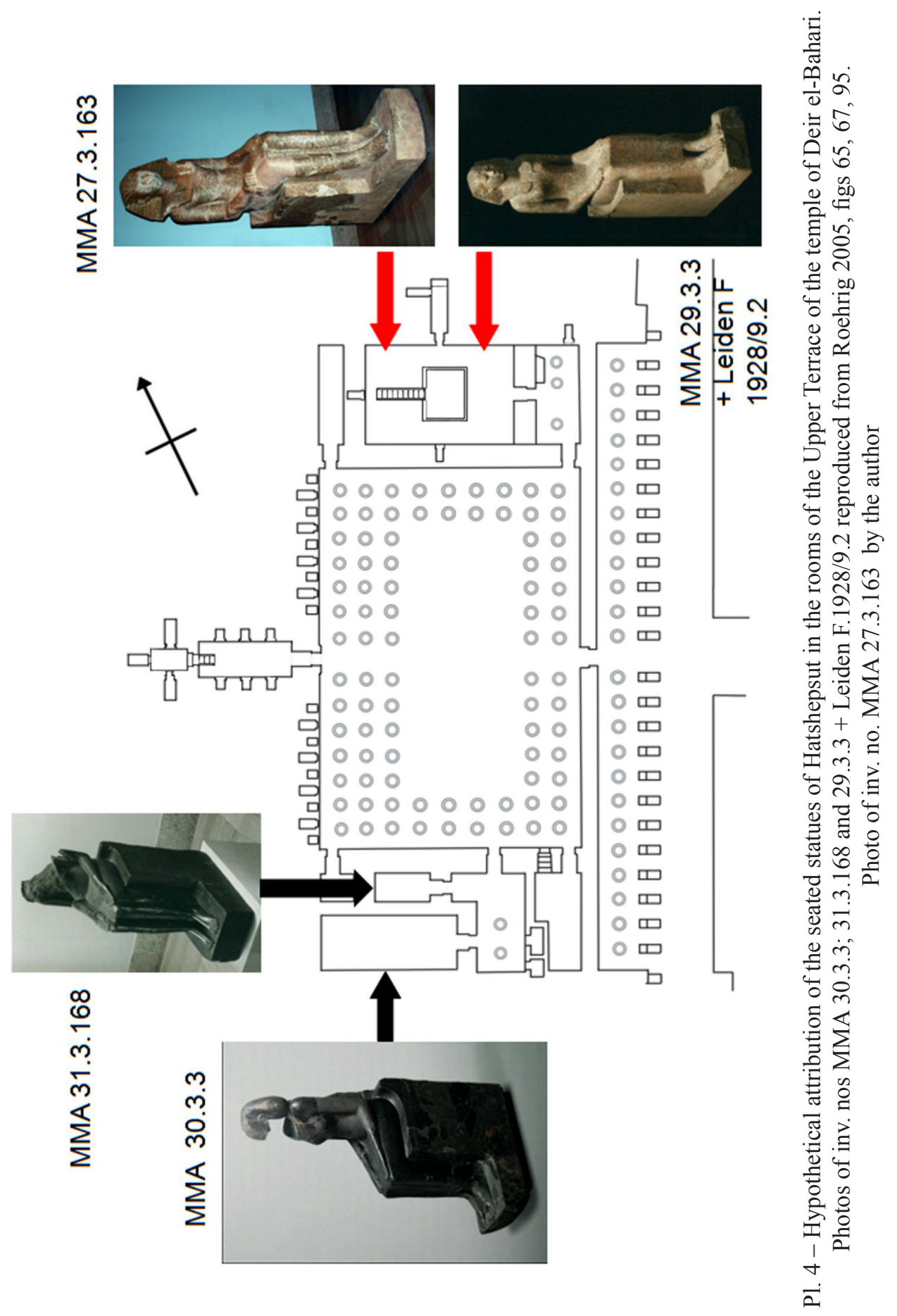




\section{Ramesside statuary}

The text on a stele of Seti I from Aswan states: 'Year 9... His Majesty caused great statues of black granite to be made. Then His Majesty discovered a new quarry for statues of black granite, whose crowns (would be) of red quartzite from the Red Mountain.' (Kitchen 1982, 35). As demonstrated by Peter Brand, however, the text refers not to granite and quartzite, but to two-coloured granodiorite/granite, the term $b j 3$ denoting not only quartzite, but also red stone in general (Brand 1998, 306-308). It seems that Seti I started and Ramesses II continued the custom of making objects of differently coloured stone with deliberately chosen border areas between veins of red granite and black granodiorite (Brand 1998, 306-308; cf. Aston et al. 2000, 35-37). These works include the naos of Seti I in Turin (Brand 1998, 154), the colossi of the Luxor temple (Brand 1998, 307-308 and n. 708), a statue of 'Young Memnon' (British Museum inv. no. EA 19; Brand 1998, 307-308, n. 709; Strudwick 2006, 202-203), a head in Cairo (Russmann 1990, 148-149), a head in Hildesheim (inv. no. 1882; Seipel 1992, 288-289, formerly attributed to Seti I) and a head in Munich (inv. no. GL 301; Ćwiek 2005, fig. 32).

\section{Obelisks}

Obelisks were royal monuments, an ideal royal $m n w$, with primarily a solar meaning (Martin 1977). As a rule, they were made of red stone, usually granite, but quartzite is also attested in the obelisks of Teti in Heliopolis (Habachi 1984, 42-43), of Seti I in Gebel Gulab quarry in West Aswan and fragments of another found in Alexandria (Brand 1998, 148, 312-313), of Ramesses IV (inv. no. CG 17026) and in two small obelisks of Seti II in front of the first pylon at Karnak (Habachi 1984, 99-101). However, the obelisks of Thoth at Hermopolis made by Nectanebo I (inv. no. BM EA 523,524 ) and also those of Thutmose III (inv. no. CG 17017), Horemheb (inv. no. CG 17018), Seti I and Ramesses II (Marseille Musée de la Vieille Charité no. 201) were made of black siltstone or greywacke (bekhenstone). The symbolism connecting red material to the sun/day and black to the moon/night was strengthened by the metals used for covering the shafts; electrum, gold or red copper was used for solar obelisks, whilst black copper was used for lunar obelisks (as proved by inscriptions on Nectanebo obelisks saying bnbnt.fm hmtj $\mathrm{km}$ 'its pyramidion is [covered] in black copper').

An obelisk from Athribis in the Poznań Archaeological Museum (P1. 3: 3), which is on loan from Berlin (inv. no. ÄMB 12800; Ćwiek 
2005, 30-31), is a special case. It is made of black granite/granodiorite, the material for which the only parallel is that of Seti I's obelisk that was found in the harbour of Alexandria (Brand 1998, 147-148). The Poznań obelisk is one of a pair, to which part of another shaft and two bases of quartzite are attributed (Schott 1939, the material of the bases is erroneously described as red granite). The bases (at present in the Cairo Museum garden) are now decorated with scenes presenting Merenptah. The inscriptions on the Poznań obelisk belong to Ramesses II, Merenptah and Seti II, but there are indications that the monument was usurped from an earlier ruler. The most probable original owner is Amenhotep III, who is known to have conducted extensive work in Athribis (Kozloff and Bryan 1992, 106-108). The Athribis obelisks were carefully designed, which is shown by the fact that the Poznan obelisk has a base of $53 \times 53 \mathrm{~cm}$ ( $1 \times 1$ cubit) and was once c. $3.6 \mathrm{~m}$ high (seven cubits; six cubits for the shaft, and one cubit for the pyramidion). It seems that the red stone for the bases and the black for the shafts was also a deliberate choice (Pl. 3: 2). The obelisk, which represented both a royal person and royal culture through its black colour, sprang up from a base of natural and primeval red, thereby expressing the same concept as black-topped pottery from the beginnings of the Egyptian civilisation.

\section{References}

Altenmüller B. 1972. Re und Herischef als ' $n b$ dšr.w'. GM 2, 9-13.

Arnold D. 1974. Der Tempel des Königs Mentuhotep von Deir el-Bahari. Band 1: Architektur und Deutung. Mainz.

Aston B. G., Harrell J. and Shaw I. 2000. Stone. In P. T. Nicholson and I. Shaw (eds), Ancient Egyptian Materials and Technology, 5-77. Cambridge.

Aufrère S. H. 1991. L'univers minéral dans la pensée égyptienne. Cairo.

Aufrère S. H. 1998. Evolution des idées concernant l'emploi des couleurs dans le mobilier et les scènes funeraires à l'Égypte jusqu'à l'époque tardive [= Autour de l'Univers minéral 13]. In S. Colinart and M. Menu (eds), La couleur dans la peinture et l'émaillage de l'Égypte ancienne. Actes de la Table Ronde, Ravello 20-22 mars 1997, 31-42. Bari. 
Aufrère S. H. 2001. The Egyptian temple, substitute for the mineral universe. In W. V. Davies (ed.), 158-163.

Baines J. 2000. Stone and other materials in ancient Egypt: usages and values. In T. de Putter and C. Karlshausen (eds), Pierres égyptiennes... Chefs-d'œuvre pour l'Éternité, 29-41. Mons.

Baines J. 2007. Visual and Written Culture in Ancient Egypt. Oxford.

Beaux N., Grimal N., Pollin G., Karkowski J. and Majerus E. 2012. La chapelle d'Hathor: temple d'Hatchepsout à Deir el-Bahari 1. Vestibule et sanctuaries. (MIFAO 129). Cairo.

Brand P. J. 1998. The Monuments of Seti I and their Historical Significance: Epigraphic, Art Historical and Historical Analysis. $\mathrm{PhD}$ thesis, University of Toronto. Toronto.

Burgos F. and Larché F. 2008. La chapelle Rouge: le sanctuaire de barque d'Hatshepsout, vol. 2. Paris.

Ćwiek A. 2003. Relief Decoration in the Royal Funerary Complexes of the Old Kingdom. Studies in Development, Scene Content and Iconography. $\mathrm{PhD}$ thesis, University of Warsaw. Warsaw. Retrieved from https://www.academia.edu/5394411/A._\%C4\%86wiek_Relief_ Decoration_in_the_Royal_Funerary_Complexes_of_the_Old_Kingdom._Studies_in_the_Development_Scene_Content_and_Iconography_PhD_Diss._University_of_Warsaw_2003 (status as of Dec. 12th, 2014).

Ćwiek A. 2005. Śmierć $i$ życie w starożytnym Egipcie. Poznań.

Ćwiek A. 2007. Red, yellow, and pink. Ideology of skin hues at Deir el-Bahari. Fontes Archeologici Posnanienses 43, 22-50.

Davies W. V. (ed.) 2001. Colour and Painting in Ancient Egypt. London.

Dodson A. 1994. The Canopic Equipment of the Kings of Egypt. London, New York.

Evers H. G. 1929. Staat aus dem Stein. Denkmäler, Geschichte und Bedeutung der ägyptischen Plastik während des Mittleren Reichs, vol. 1. Munich.

Frankfort H. 1933. The Cenotaph of Seti I at Abydos, vol. 1. London.

Friedman R. F. 2002. Egypt and Nubia: Gifts of the Desert. London.

Friedman R. F. 2009. Hierakonpolis locality HK29A: the Predynastic ceremonial centre revisited. JARCE 45, 79-103.

Gabolde L. 2005. Monuments décorés en bas relief aux noms de Thoutmosis II et Hatchepsout à Karnak. (MIFAO 103). Cairo. 
Griffiths J. G. 1972. The symbolism of red in Egyptian religion. In Ex Orbe Religionum. Studia Geo Widengren XXIV Mense Apr. MCMLXXII quo die lustra tredecim feliciter explevit oblata ab collegis, discipulis, amicis, collegae magistro amico congratulantibus, 81-90. Leiden.

Habachi L. 1984. The Obelisks of Egypt. Skyscrapers of the Past. Cairo.

Hoffmeier J. K. 1993. The use of basalt in floors of Old Kingdom pyramid temples. JARCE 30, 117-123.

Karkowski J. 2005. Deir el-Bahari 6. The Solar Complex in Hatshepsut's Temple at Deir el-Bahari. Warsaw.

Kees H. 1943. Farbensymbolik in ägyptischen religiösen Texten. In NAWG. Philologisch-historische Klasse 11, 413-479.

Keller C. A. 2005. Statuary of Hatshepsut. In C. H. Roehrig, R. Dreyfus and C. A. Keller (eds), Hatshepsut: From Queen to Pharaoh, 158-172. New York.

Kitchen K. 1982. Pharaoh Triumphant. The Life and Times of Ramesses II. Warminster.

Kozloff A. P. and Bryan B. M. 1992. Egypt's Dazzling Sun. Amenhotep III and his World. Cleveland.

Manniche L. 1979. The complexion of Queen Ahmosi Nefertere. AcOr 40, 11-19.

Manniche L. 1982. The body colours of gods and men in inlaid jewellery and related objects from the Tomb of Tutankhamun. AcOr 43, 5-13.

Martin K. 1977. Ein Garantssymbol des Lebens. Untersuchung zu Ursprung und Geschichte der altägyptischen Obelisken bis zum Ende des Neuen Reiches. (Hildesheimer Ägyptologische Beiträge 3). Hildesheim.

Mathieu B. 2009. Les couleurs dans les Textes des Pyramides: approche des systèmes chromatiques. Égypte Nilotique et Méditerranéenne 2, 25-52.

Murnane W. 1995. Texts from the Amarna Period in Egypt. (American Academy of Religion Academy Series 5). Atlanta.

Naville E. 1906. The Temple of Deir el Bahari, part 5. (EEF 27). London.

Pinch G. 2001. Red things: the symbolism of colour in magic. In W. V. Davies (ed.), 182-185.

Robins G. 2002. Color symbolism. In D. B. Redford (ed.), Oxford Encyclopedia of Ancient Egypt, vol. 1, 291-294. Oxford.

Roehrig C. H. (ed.) 2005. Hatshepsut: from Queen to Pharaoh. New York. 
Russmann E. R. and Finn D. 1990. Egyptian Sculpture: Cairo and Luxor. London.

Saleh M. and Sourouzian H. 1987. The Egyptian Museum Cairo: Official Catalogue. Mainz.

Schott S. 1939. Zwei Obeliskensockel aus Athribis. MDAIK 8,190-197.

Seipel W. 1992. Gott - Mensch - Pharao. Viertausend Jahre Menschenbild in der Skulptur des Alten Ägypten. Vienna.

Servajean F. 2013. Duality. In J. Dieleman and W. Wendrich (eds), UCLA Encyclopedia of Egyptology. Los Angeles. Retrieved from http://repositories.edlib.org/elc/uee/1005 (status as of Dec. 13th, 2013).

Silverman D. P. 1980. Cryptographic writing in the tomb of Tutankhamun. SAK 8, 233-236.

Strudwick N. 2006. Masterpieces of Ancient Egypt from the British Museum. Cairo.

Westendorf W. 1966. Altägyptische Darstellungen des Sonnenlaufes auf der abschüssigen Himmelsbahn. (MÄS 10). Berlin.

Wilkinson R. 1994. Symbol and Magic in Egyptian Art. London.

Wissa M. 1994. Le sarcophage de Merenrê et l'expédition à Ibhat (I). In C. Berger, G. Clerc and N. Grimal (eds), Hommages à Jean Leclant. Vol. 1: Études pharaoniques, 379-387. Cairo.

Andrzej Ćwiek Institute of Prehistory Adam Mickiewicz University Poznań Archaeological Museum andrzejcwiek@yahoo.com 